\title{
On the relative role of convection, chemistry, and transport over the South Pacific Convergence Zone during PEM-Tropics B: A case study
}

\section{Citation}

Mari, Céline, Carine Saüt, Daniel J. Jacob, Amanda Staudt, Melody A. Avery, William H. Brune, Ian Faloona, et al. 2002. "On the Relative Role of Convection, Chemistry, and Transport over the South Pacific Convergence Zone During PEM-Tropics B: A Case Study." Journal of Geophysical Research 108 (D2) (November 16). doi:10.1029/2001jd001466.

\section{Published Version}

doi:10.1029/2001JD001466

\section{Permanent link}

http://nrs.harvard.edu/urn-3:HUL.InstRepos:14121758

\section{Terms of Use}

This article was downloaded from Harvard University's DASH repository, and is made available under the terms and conditions applicable to Other Posted Material, as set forth at http:// nrs.harvard.edu/urn-3:HUL.InstRepos:dash.current.terms-of-use\#LAA

\section{Share Your Story}

The Harvard community has made this article openly available.

Please share how this access benefits you. Submit a story. 


\title{
On the relative role of convection, chemistry, and transport over the South Pacific Convergence Zone during PEM-Tropics B: A case study
}

\author{
Céline Mari, ${ }^{1}$ Carine Saüt, ${ }^{1}$ Daniel J. Jacob, ${ }^{2}$ Amanda Staudt, ${ }^{2}$ Melody A. Avery, ${ }^{3}$ \\ William H. Brune, ${ }^{4}$ Ian Faloona, ${ }^{5}$ Brian G. Heikes, ${ }^{6}$ Glen W. Sachse, ${ }^{7}$ \\ Scott T. Sandholm, ${ }^{8}$ Hanwant B. Singh, ${ }^{9}$ and David $\operatorname{Tan}^{8}$ \\ Received 6 November 2001; revised 24 April 2002; accepted 24 April 2002; published 16 November 2002.
}

[1] A mesoscale 3D model (Meso-NH) is used to assess the relative importance of convection (transport and scavenging), chemistry, and advection in the vertical redistribution of $\mathrm{HO}_{x}$ and their precursors in the upper tropical troposphere. The study is focused on marine deep convection over the South Pacific Convergence Zone (SPCZ) during the PEM-Tropics B Flight 10 aircraft mission. The model reproduces well the $\mathrm{HO}_{x}$ mixing ratios. Vertical variations and the contrast between north and south of the SPCZ for $\mathrm{O}_{3}$ are captured. Convection uplifted $\mathrm{O}_{3}$-poor air at higher altitude, creating a minimum in the $9-12 \mathrm{~km}$ region, in both modeled and observed profiles. The model captured $60 \%$ of the observed $\mathrm{HCHO}$ variance but fails to reproduce a peak of $\mathrm{HCHO}$ mixing ratio at 300 $\mathrm{hPa}$ sampled during the northern spirals. Simulated $\mathrm{HCHO}$ mixing ratios underestimate observations in the marine boundary layer. In the model, convection is not an efficient process to increase upper tropospheric $\mathrm{HCHO}$, and $\mathrm{HCHO}$ is unlikely to serve as a primary source of $\mathrm{HO}_{x}$. Convection plays an important role in the vertical distribution of $\mathrm{CH}_{3} \mathrm{OOH}$ with efficient vertical transport from the boundary layer to the $10-15 \mathrm{~km}$ region where it can act as a primary source of $\mathrm{HO}_{x}$. The SPCZ region acts as a barrier to mixing of tropical and subtropical air at the surface and at high altitudes (above $250 \mathrm{hPa}$ ). The $400-270 \mathrm{hPa}$ region over the convergence zone was more permeable, allowing subtropical air masses from the Southern Hemisphere to mix with tropical air from NE of the SPCZ and to be entrained in the SPCZ-related convection. In this altitude range, exchange of subtropical and tropical air also occurs via airflow, bypassing the convective region SW and proceeding toward the north of the SPCZ. INDEX TERMS: 0320 Atmospheric Composition and Structure: Cloud physics and chemistry; 0365 Atmospheric Composition and Structure: Troposphere-composition and chemistry; 0368 Atmospheric Composition and Structure: Troposphere - constituent transport and chemistry; 3314 Meteorology and Atmospheric Dynamics: Convective processes; KEYWORDS: convection, SPCZ, PEMTropics, mesoscale model, $\mathrm{HO}_{x}$

Citation: Mari, C., et al., On the relative role of convection, chemistry, and transport over the South Pacific Convergence Zone during PEM-Tropics B: A case study, J. Geophys. Res., 107, 8232, doi:10.1029/2001JD001466, 2002. [printed 108(D2), 2003]

\footnotetext{
${ }^{1}$ Laboratoire d'Aérologie, UMR CNRS/Université Paul Sabatier, Toulouse, France.

${ }^{2}$ Division of Engineering and Applied Science, Harvard University, Cambridge, Massachusetts, USA.

${ }^{3}$ Department of Physics, Hampton University, Hampton, Virginia, USA.

${ }^{4}$ Department of Meteorology, Pennsylvania State University, University Park, Pennsylvania, USA.

${ }^{5}$ Atmospheric Chemistry Division, National Center for Atmospheric Research, Boulder, Colorado, USA.

${ }^{6}$ Center for Atmospheric Chemistry Studies, University of Rhodes Island, Narragansett, Rhodes Island, USA.

${ }^{7}$ Aerospace Electronic Research Division, NASA Langley Research Center, Hampton, Virginia, USA.

${ }^{8}$ Earth and Atmospheric Sciences, Georgia Institute of Technology, Atlanta, Georgia, USA.

${ }^{9}$ NASA Ames Research Center, Moffett Field, California, USA.
}

Copyright 2002 by the American Geophysical Union.

0148-0227/02/2001JD001466

\section{Introduction}

[2] Deep convection plays a critical role in determining the vertical structure of the atmosphere. From a large-scale point of view, convection is an essential dynamical process to uplift air from the boundary layer to higher altitudes, seeding the upper troposphere with pollutants. At these high altitudes, air more likely experiences long-range transport. Deep convection is thus a major actor for intercontinental and interhemispheric transport in the troposphere [Collins et al., 1999; Cooper et al., 2001]. At local scale, rapid convective injection yields air with a much different chemical signature than slow ascent [Pickering et al., 1996; Prather and Jacob, 1997; Gettelman et al., 2001] However, assessing the chemical signatures of convection is a nontrivial exercise. Convection can have both a direct effect by uplifting poor or rich boundary 
layer material to the upper troposphere, and an indirect (sometimes counteracted) effect by replenishing upper troposphere with precursors or consumptors [Folkins et al., 2002]. In terms of the supply of hydrogen oxide radicals $\left(\mathrm{HO}_{x}=\mathrm{OH}+\mathrm{HO}_{2}\right)$, recent studies have shown that the upper troposphere is more photochemically active than previously thought due to the convective transport of $\mathrm{HO}_{x}$ precursors [McKeen et al., 1997; Wennberg et al., 1998, 1999; Jaeglé et al., 1997, 2001]. An unresolved issue is the relative contribution of advection, convection and local chemistry to the in the upper troposphere.

[3] In this study, we present an analysis of the South Pacific Convergence Zone (SPCZ) during the PEMTropics B Flight 10 in March 1999 [Raper et al., 2001]. The SPCZ is a persistent, well defined convective cloud band and acts as a barrier between tropical and subtropical air masses of the western South Pacific ocean, particularly at lower tropospheric levels [Gregory et al., 1999; Vincent, 1994]. Thus, SPCZ is particularly well suited for a study of the vertical transport and scavenging of chemical species by convection with marked gradients of chemical concentrations both sides of the cloud band.

[4] Flight 10 has been well documented in two previous papers. Pickering et al. [2001] used a two-dimensional model to quantify the convective mixing, lightning $\mathrm{NO}_{x}$ production and wet scavenging of soluble species during this flight. The authors found that little NO were produced by electrical discharges within the SPCZ convection. $90 \%$ of and $\mathrm{HNO}_{3}$ and $\mathrm{H}_{2} \mathrm{O}_{2}$ were removed by convective precipitation during cloud transport in the $2 \mathrm{D}$ model. Convective transport of low NO marine boundary layer to the upper troposphere reduced ozone production by $60 \%$ compared to air undisturbed by convection. Mari et al. [2002] used a zero-dimensional model to contrast the relative contributions of different sources of upper tropospheric $\mathrm{HO}_{x}$ during that flight. The conclusion was that the primary sources $\mathrm{HO}_{x}$ of varied significantly along the flight track in correlation with the supply of water vapor. Production from acetone became significant in drier region south of $20^{\circ} \mathrm{S}$. Over the SPCZ region, in the cloud outflow, $\mathrm{CH}_{3} \mathrm{OOH}$ transported by convection accounts for $22-64 \%$ of the total primary source. In this work, our approach is based on a three-dimensional model coupled on-line with chemistry and an entraining/ detraining plume model. Our goal is to estimate the relative importance of the advection, convection, and in situ chemical processes in determining the vertical structure and evolution of $\mathrm{HO}_{x}$ and their precursors $\left(\mathrm{H}_{2} \mathrm{O}_{2}\right.$, $\mathrm{CH}_{3} \mathrm{OOH}$, and $\mathrm{HCHO}$ ). The three-dimensional mesoscale model provides an integrative tool to study the interplay between the dynamical and physicochemical processes at regional scale.

\section{Model Description}

[5] The model used in this study is a nonhydrostatic mesoscale model, Meso-NH, coupled on-line with chemistry. A detailed description of the dynamics and chemistry of the model can be found in the literature (http://www. aero.obs-mip.fr/mesonh) [Lafore et al., 1998; Tulet et al., 2002; Mari et al., 1999; Suhre et al., 2000]. The on-line coupling more easily enables for a maximum coherence between transport schemes (advection, convection, prognostic turbulence mixing) and the treatment of the chemical components. Model horizontal resolution is $40 \times 40$ $\mathrm{km}$. Vertical resolution is $50 \mathrm{~m}$ in the boundary layer and 300 in the free troposphere up to $20 \mathrm{~km}$, with a total of 62 levels. Time step is $50 \mathrm{~s}$ for dynamics. The chemical mechanism is integrated in the model with the QSSA solver [Hesstvedt et al., 1978]. TUV model is used to compute photolysis rates as a function of solar zenith angle [Madronich and Weller, 1990] (R. E. Shetter et al., Comparison of photolysis frequencies determined by scanning actinic flux spectroradiometry (SAFS) with the NCAR radiative transfer model (TUV) during the PEMTropics B mission, submitted to Journal of Geophysical Research, 2001) and a correction of the rate below and above cloud is applied [Chang et al., 1987]. A reduced chemical scheme is used [Crassier et al., 1999], including 39 prognostic species and 128 reactions. Scavenging by convective precipitation has been implemented following the work of Mari et al. [2000]. Large-scale forcing for dynamical parameters are provided by the ECMWF analysis. Initialization and boundary conditions of chemical species are provided by the Harvard/Florida State University (FSU) CTM model [Staudt et al., 2001] for the PEMTropics $\mathrm{B}$ meteorological period. Acetone and $\mathrm{CH}_{3} \mathrm{OOH}$ are not simulated well by that model for the PEM-Tropics B environment [Singh et al., 2001]. Therefore we imposed initial and boundary conditions for these species on the basis of the aircraft observations.

\section{Meteorological Conditions}

\subsection{Background Meteorology During Flight 10}

[6] Flight 10 was dedicated to the study of SPCZ convection [Mari et al., 2002; Pickering et al., 2001]. The flight traversed the extensive and strong band of convection, sampling air masses on both sides of the SPCZ and in the convective outflow (Figure 1). Two spiral points were located on either side of the SPCZ area. The flight started from Fiji on 20 March at 2230 UTC (20 March at 0930 Local Solar time) and ended on 21 March at 0615 UTC (20 March at 1715 Local Solar Time).

[7] The meteorology of the SPCZ is described in detail by Fuelberg et al. [2001] and Vincent [1994]. Here, we summarize the main features of the meteorological situation during Flight 10 and discuss the model's capability to simulate the dynamics. The SPCZ region is characterized by a diagonal band of convective clouds oriented NW-SE as illustrated by the satellite image (Figure 1). The SPCZ lies in a region of low-level moisture convergence, between the predominantly northeasterly flow and the cooler predominantly southeasterly flow at higher latitude. This extensive and persistent cloud bands is well reproduced by the model as shown in Figure 2. South of the SPCZ is characterized by a large-scale subsidence associated with the jet stream. The core of the upper tropospheric subtropical jet was located near $30^{\circ} \mathrm{S}$ and the jet streak was around $13 \mathrm{~km}$ altitude. Wind speed and direction, potential temperature, and water vapor mixing ratio are well reproduced by the model as shown in Figures 3 and 4. In particular, as the flight track crossed the SPCZ region at 10 and $11.3 \mathrm{~km}$, sudden change in wind speed and direction were well captured by the 


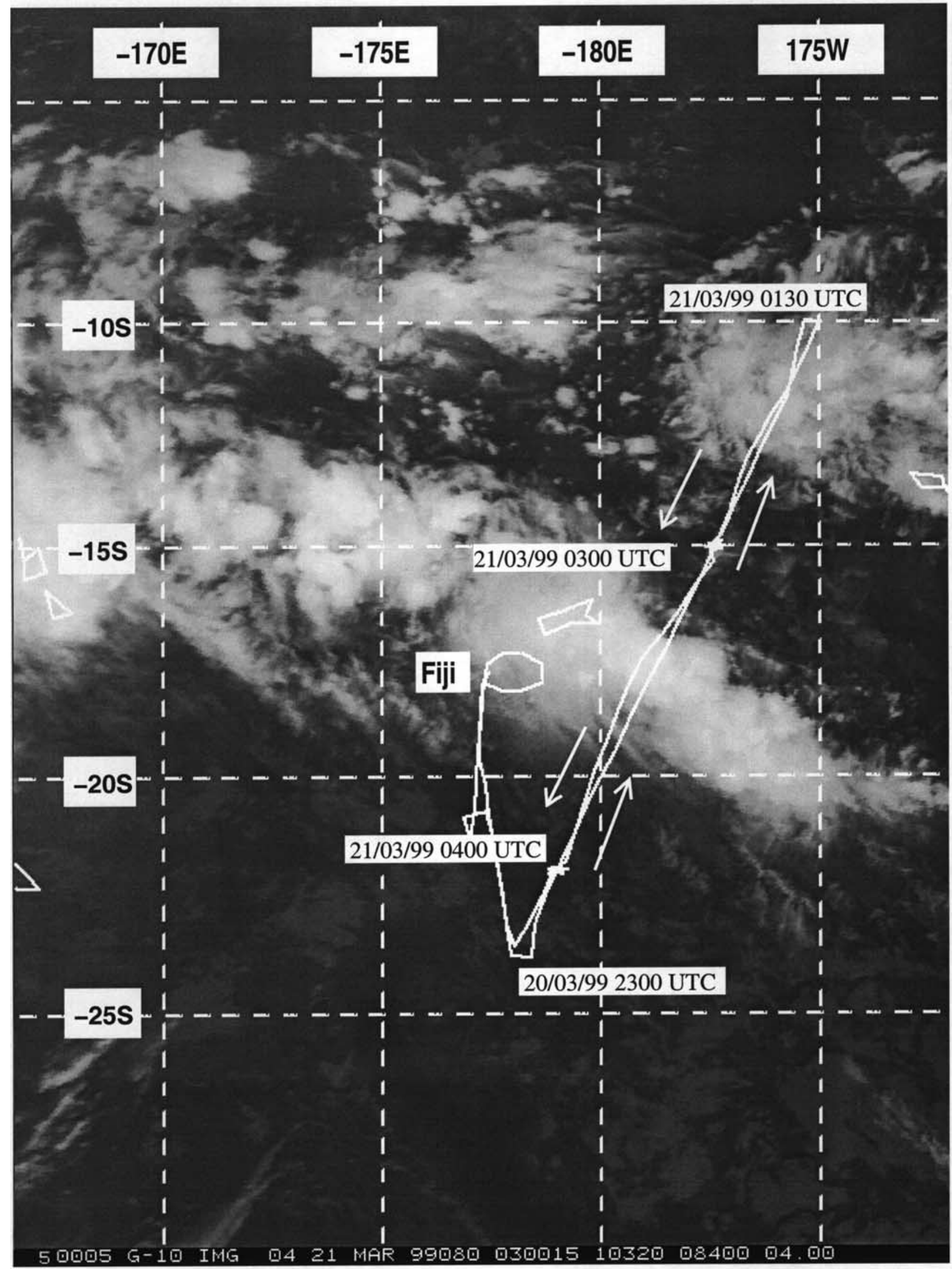

Figure 1. GEOS-10 IR satellite image for 21 March at 0300 UTC with track of Flight 10 during PEMTropics B experiment. Flight 10 started on 20 March at 2230 UTC from Fiji and returned on 21 March at 0615 UTC. 


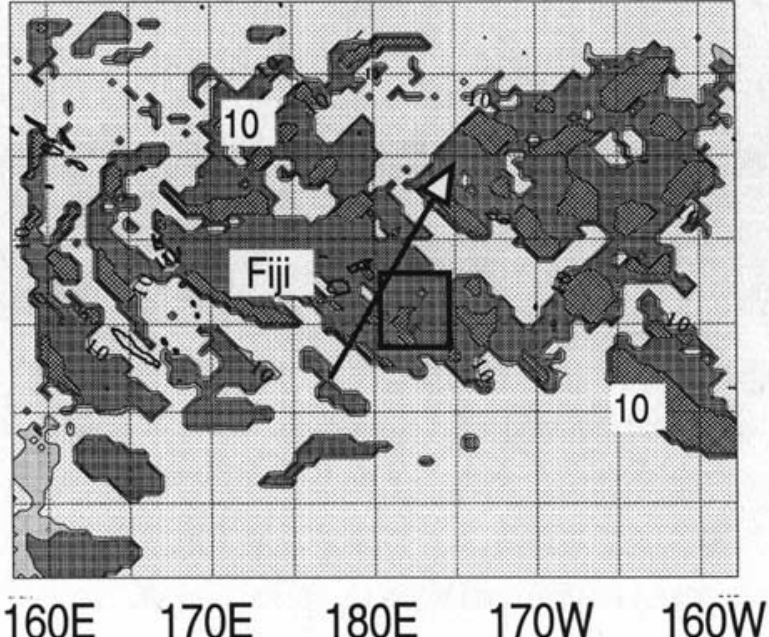

(a)

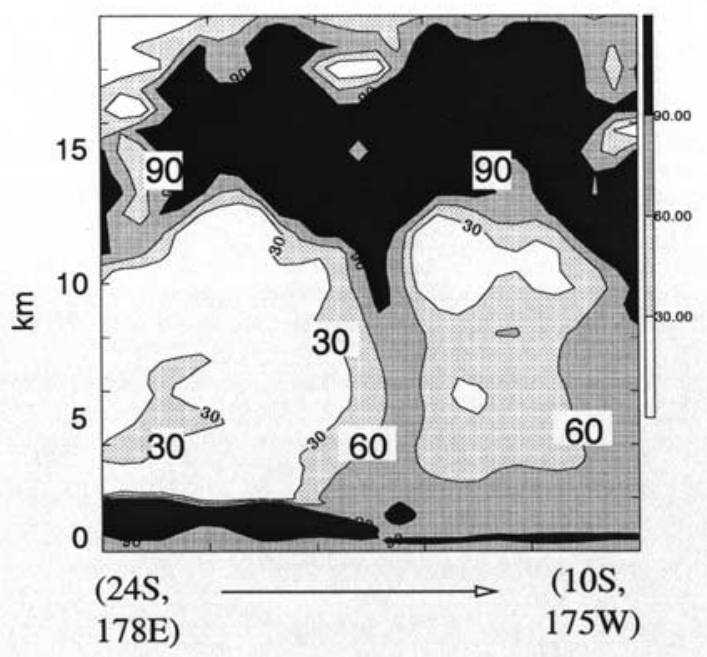

(c)

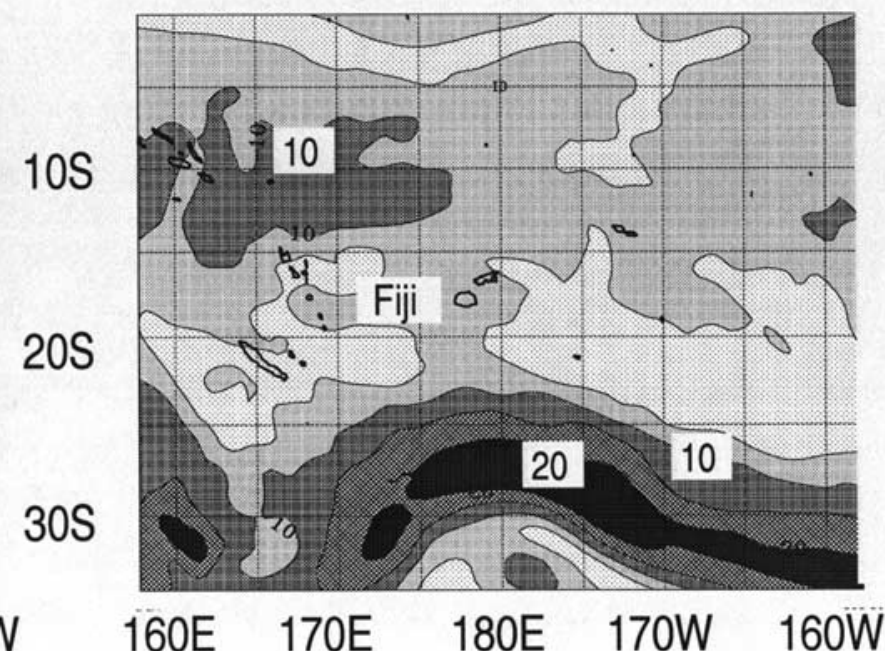

(b)

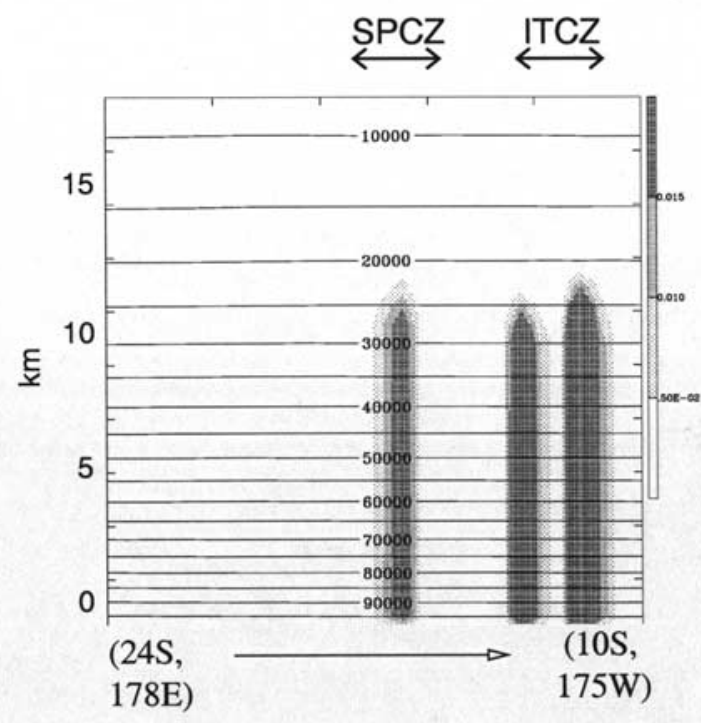

(d)

Figure 2. (a) Simulated cloud height (in $\mathrm{km}$ ) on 21 March at 0300 UTC. The square represents the area of budget calculations and is commensurate with the SPCZ-related convection traversed by the flight. (b) Simulated wind speed (in $\mathrm{m} / \mathrm{s}$ ) at $330 \mathrm{~K}$ with the subtropical jet stream south of the SPCZ. (c) Simulated cross sections along the flight track of relative humidity. (d) Same as (c), but for updraft convective mass flux (in $\mathrm{kg} / \mathrm{s}$ ). The dotted lines represent the pressure (in $\mathrm{Pa}$ ).

model. South of the SPCZ was characterized by SW elevated strong wind speed $(18 \mathrm{~m} / \mathrm{s})$ whereas north of the SPCZ has lower wind speed (around $10 \mathrm{~m} / \mathrm{s}$ ) and NE flow. It is worth noting that in areas of convection, the winds tend to be less reliable because of the influence of small-scale motions. The measured winds contain an influence from the convection, and are not simply describing the large-scale environmental flow. In Figure 4, observed and simulated water vapor mixing ratios in the upper troposphere in the SPCZ and ITCZ regions were relatively high (median values respectively 296 and 354 ppmv) compared to the region south of the SPCZ (median value $86 \mathrm{ppmv}$ ) These results confirm the capability of the model to reproduce the important meteorological features observed during PEMTropics B Flight 10.

\subsection{Advection and Convection in the SPCZ Region}

[8] Figure 5 shows the airflow at three different altitudes together with the accumulated ground convective precipitation. Ground precipitation is plotted here to serve as an indicator of the convergence zone. Near the surface, boundary layer air north of the SPCZ is entrained in the convective clouds. It is worth noting that near the surface $(950 \mathrm{hPa})$ and at very low pressure $(200 \mathrm{hPa})$, the SPCZ acts as a barrier to mixing of tropical and subtropical air. On the contrary, in the $400-270 \mathrm{hPa}$ region, the conver- 
a)

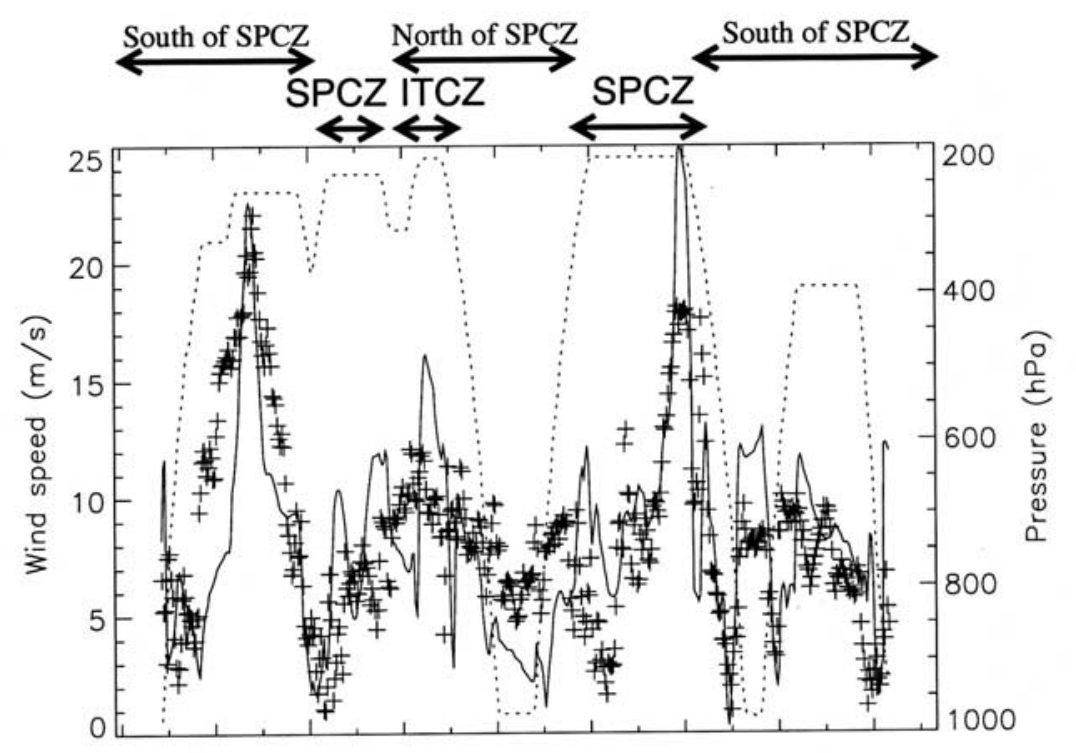

b)

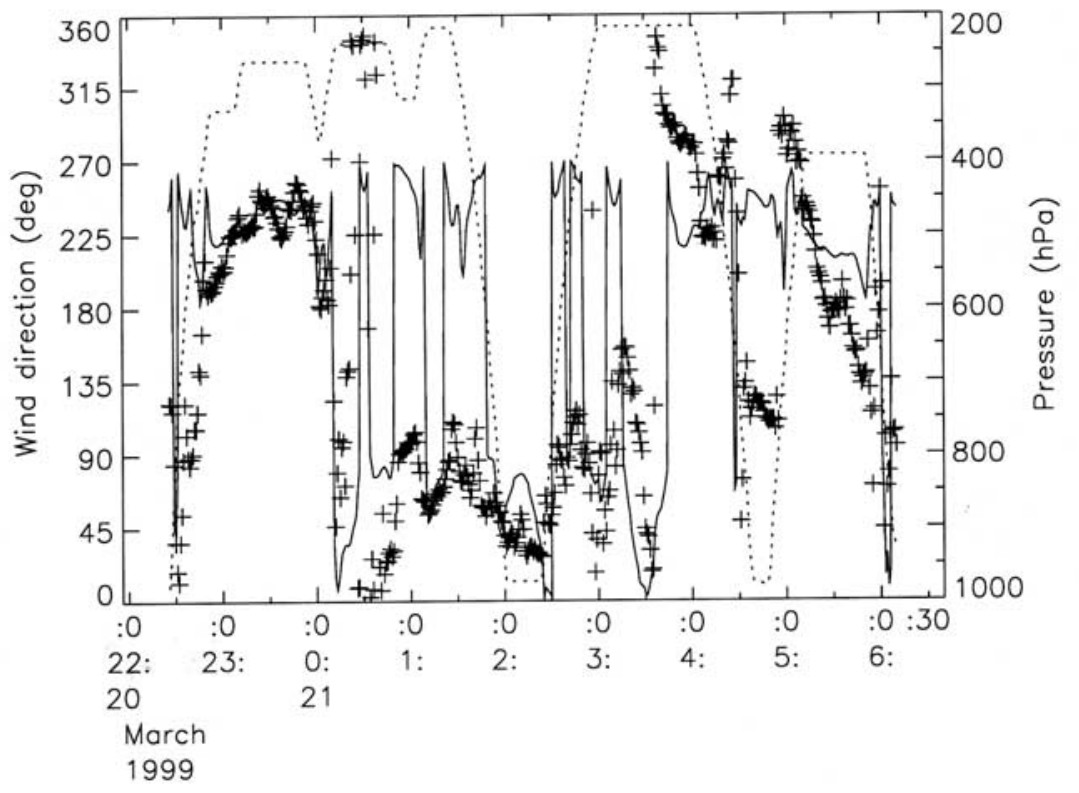

Figure 3. (a) Observed wind speed obtained from the aircraft (crosses) and simulated wind speed (solid line) (in $\mathrm{m} / \mathrm{s}$ ) during Flight 10 as a function of time. Model results are linearly interpolated along the flight track. The entire flight took place during daytime, crossing the SPCZ twice during the outbound and returning part of the flight. (b) Same for wind direction (in degrees).

gence zone becomes porous allowing subtropical air masses from the Southern Hemisphere to mix with tropical air from NE of the SPCZ. These results extend the hypothesis of Pickering et al. [2001]. The authors stated that mixing in tropical air from NE of the SPCZ with Southern Hemisphere subtropical air from SW of the SPCZ occurred in the upper troposphere, above and near the cloud band top. The present study suggests that air south of the SPCZ can also traverse the SPCZ at midtropospheric levels where it is entrained in the convective clouds. In addition to this mixing over the cloudy region, airflow at $400 \mathrm{hPa}$, also reveals a significant flow counterclockwise going round the convective zone, SW of the SPCZ. This flow brings Southern Hemisphere air to the north of the
SPCZ, therefore favoring air mass exchange between the two hemispheres. Figure $2 \mathrm{~d}$ shows updraft convective mass fluxes along the flight track. Convective updraft mass fluxes in Figure 2d have parabolic profiles consistent with entrainment of air in the 900-270 $\mathrm{hPa}$ region. Convective cloud outflow in the SPCZ and ITCZ regions occurs in the 250-200 hPa region. Air detrained in the $250-200 \mathrm{hPa}$ region is then advected toward the E-SE according to Figure 5c.

\section{Chemical Signatures in the SPCZ Region}

[9] In the following sections, the chemical signatures of the different air masses in the SPCZ region are presented. 
a)

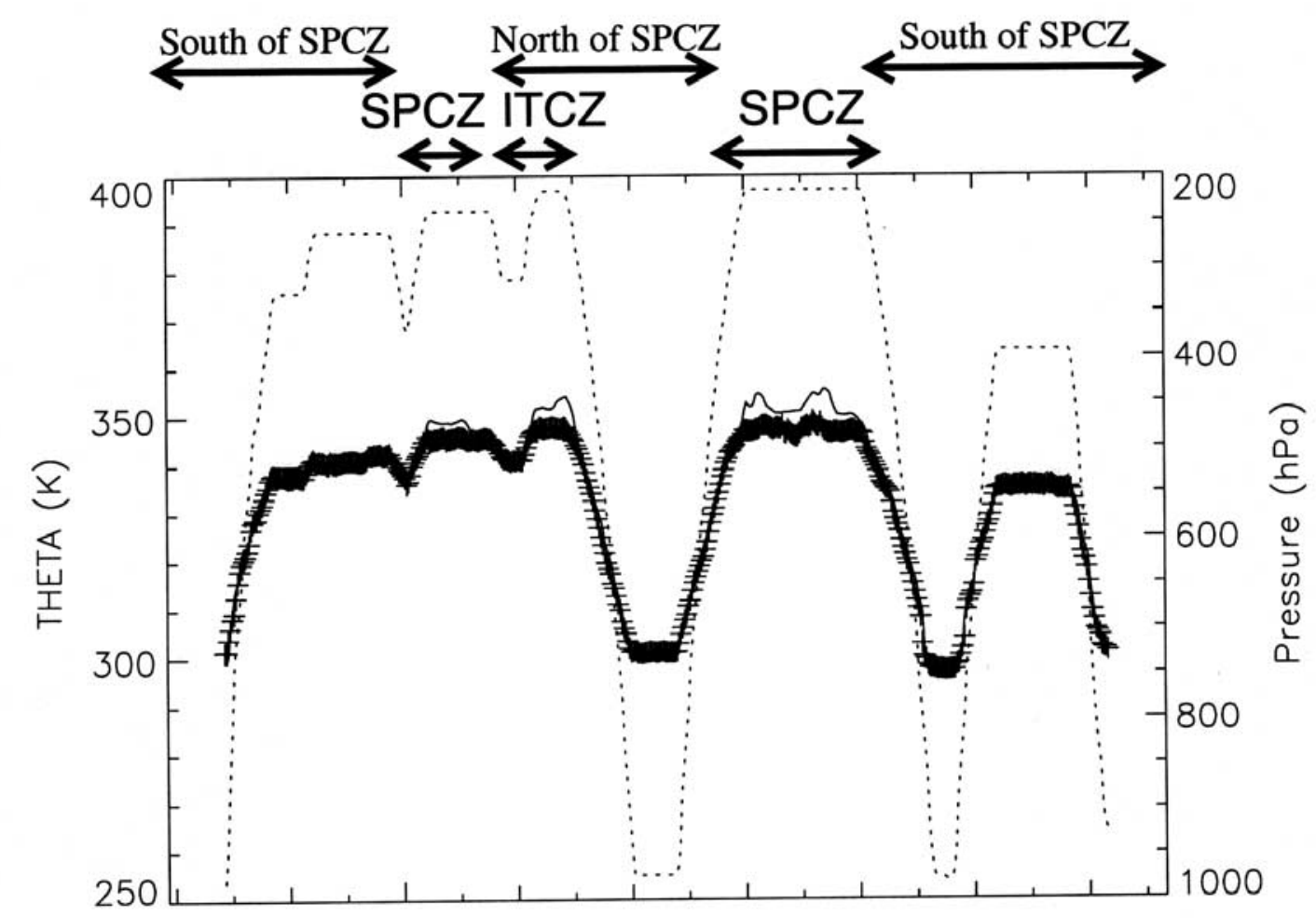

b)

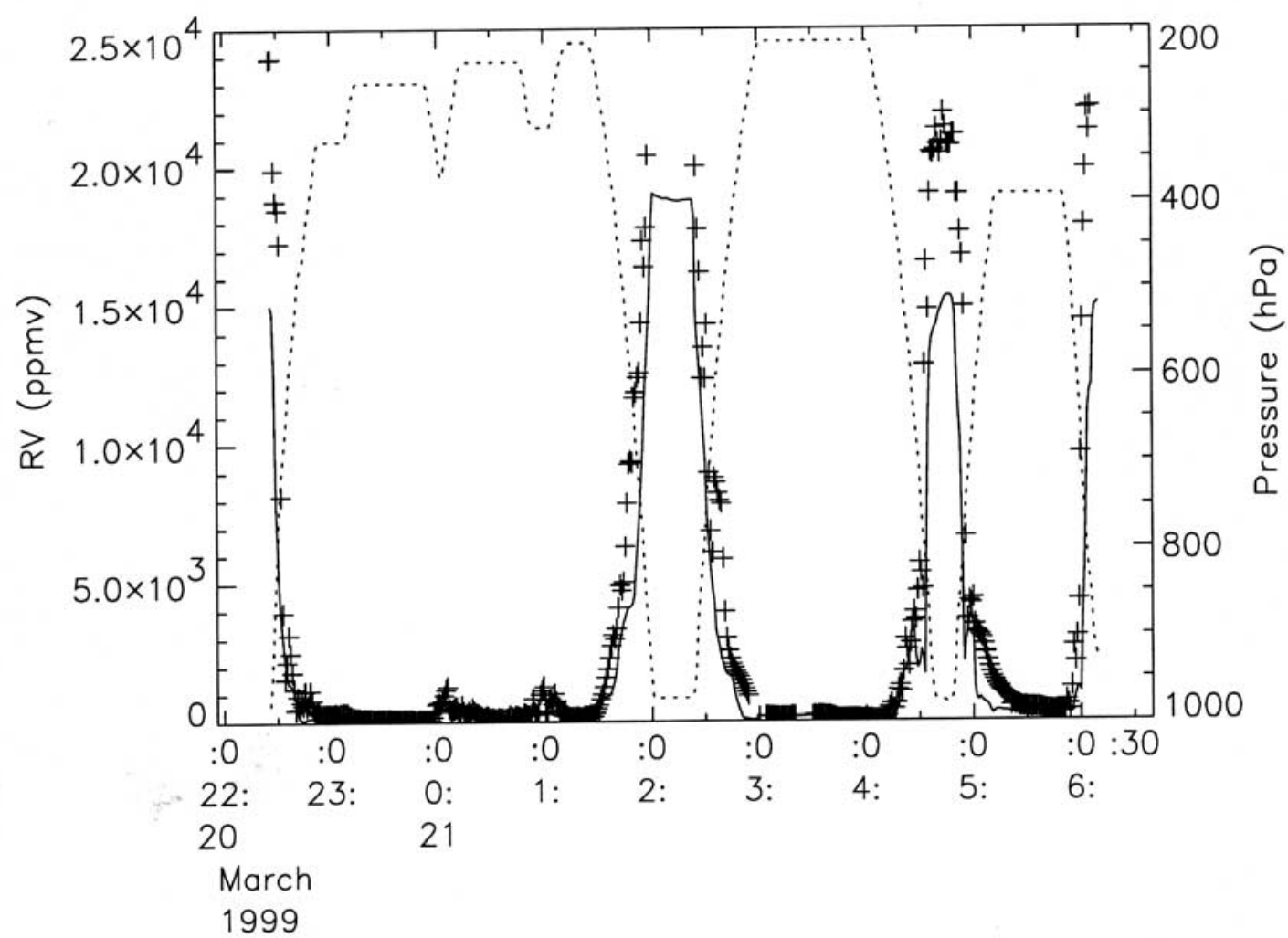

Figure 4. (a) Same as Figure 3, but for potential temperature (in K). (b) Same as (a), but for water vapor mixing ratio (in ppmv). 
(a)
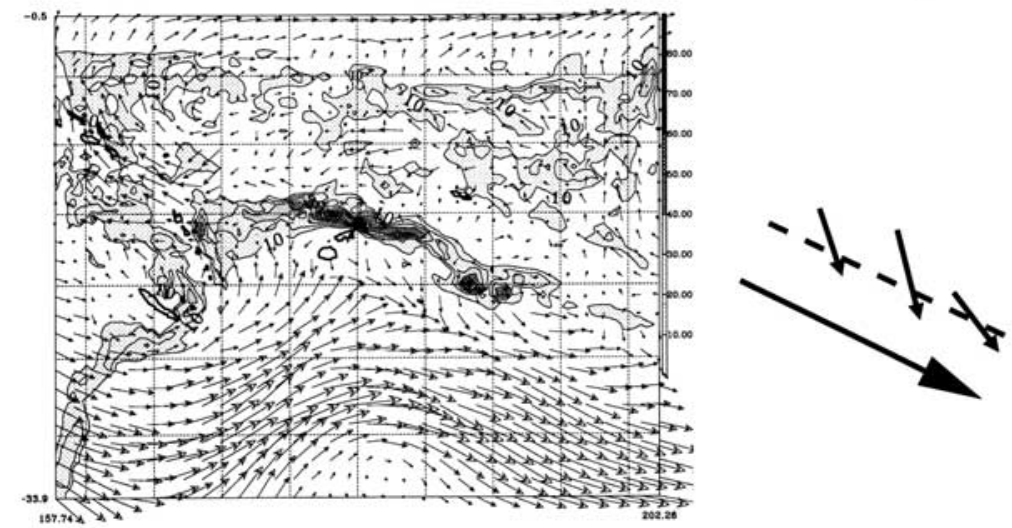

(b)
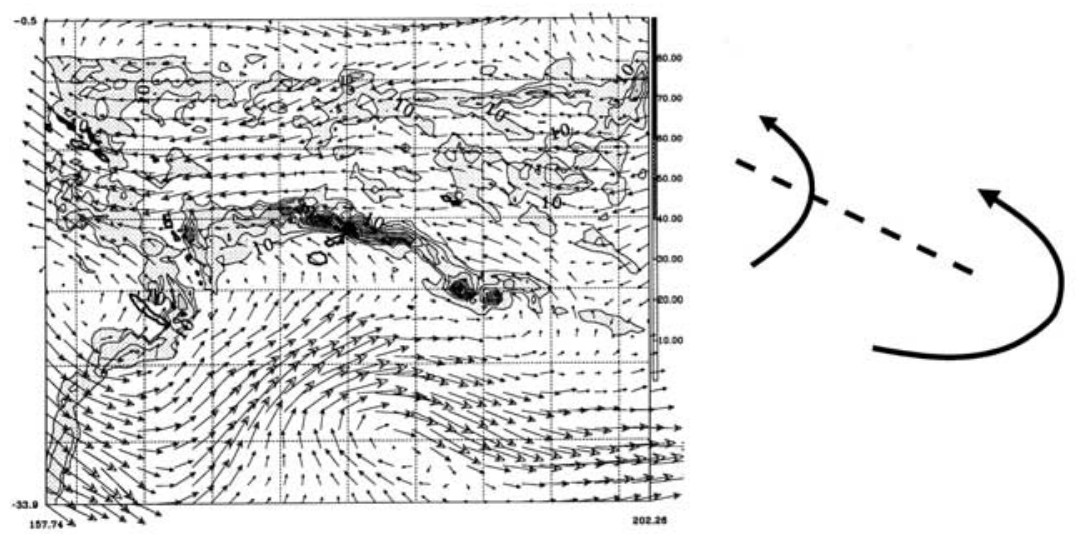

(c)


Figure 5. Accumulated ground precipitation (in $\mathrm{mm}$ ) on 21 March at 0300 UTC (after 21 hours of simulation) and wind at (a) $200 \mathrm{hPa}$, (b) $400 \mathrm{hPa}$, and (c) $950 \mathrm{hPa}$.

The capability of the model to reproduce these chemical signatures is discussed. Budget calculations in the model are performed to assess the relative impact of convection, advection, and chemistry on $\mathrm{HO}_{x}$ precursors over the SPCZ-related convection area.

\subsection{Observed and Simulated Chemical Signature}

[10] Chemical variations observed across the SPCZ at 200-300 hPa on both the outbound and the inbound flight segments reflected the transition between subtropical and tropical air masses as well as strong convective influence within the SPCZ itself [Mari et al., 2002].

[11] In the southern part of the track (south of $20^{\circ} \mathrm{S}$ ), relatively high concentrations of ozone (mean value 32 ppbv), NO (mean value 29 pptv) and small enhancements of $\mathrm{CO}$ (up to $58 \mathrm{ppbv}$ ) were measured suggesting some continental influence from Australia [Pickering et al., 2001]. Observed $\mathrm{HCHO}$ and $\mathrm{CH}_{3} \mathrm{OOH}$ mixing ratios 


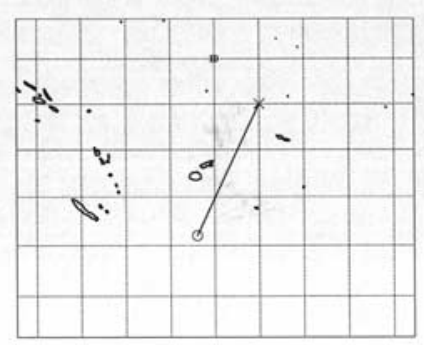

(a)

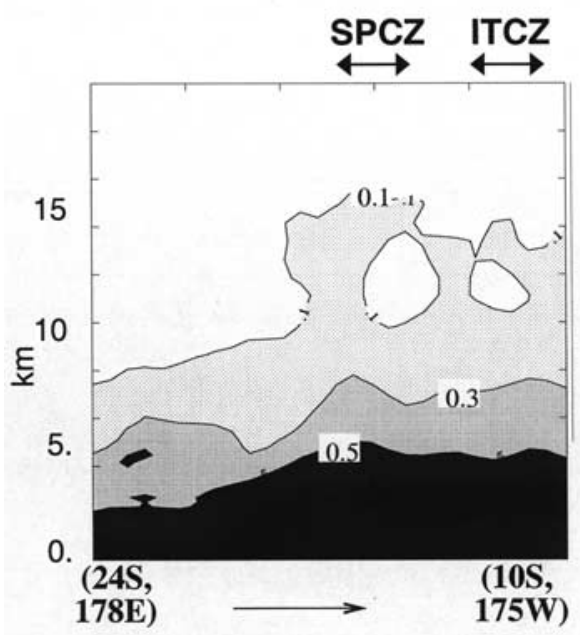

(d)



(b)

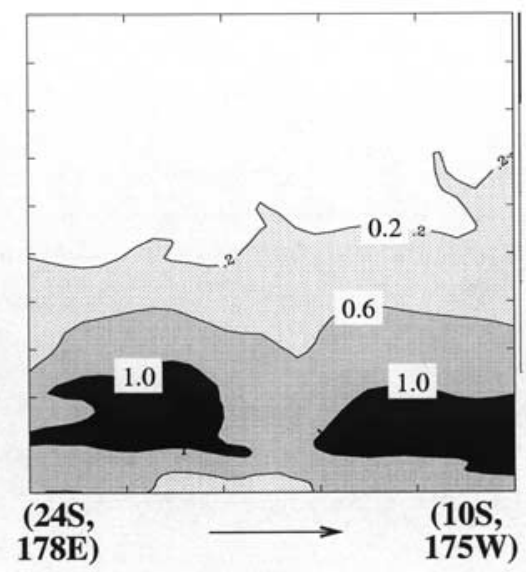

(e)

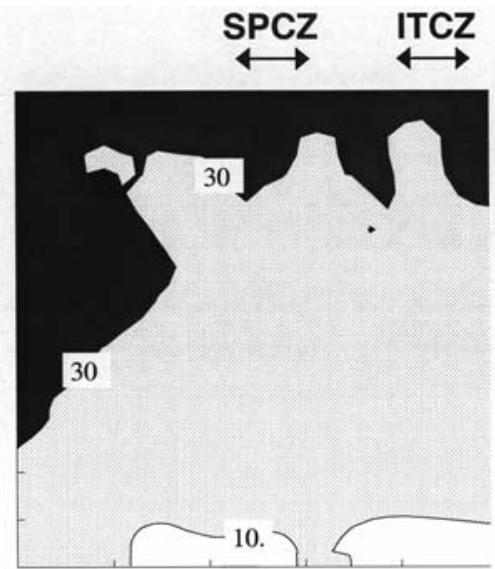

(c)

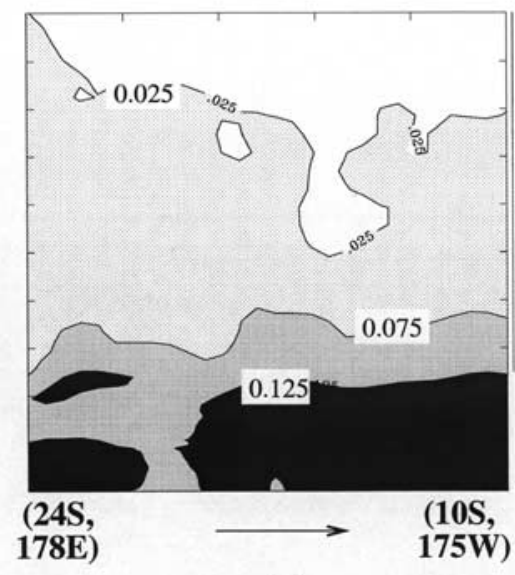

(f)

Figure 6. Simulated cross sections along the flight track (a) on 21 March at 0300 UTC for (b) CO (in ppbv), (c) $\mathrm{O}_{3}$ (in ppbv), (d) $\mathrm{CH}_{3} \mathrm{OOH}$ (in ppbv), (e) $\mathrm{H}_{2} \mathrm{O}_{2}$ (in ppbv), and (f) $\mathrm{HCHO}$ (in ppbv). Double arrows represent the locations of the SPCZ and ITCZ.

in the upper troposphere, south of the SPCZ, were relatively low (median values 80 and $70 \mathrm{pptv}$, respectively). In this region, because of the strong subsidence associated with the upper tropospheric subtropical jet, water vapor concentrations were low (median value 86 ppmv). In contrast, for the region north of the SPCZ, influenced by convection, observed upper tropospheric $\mathrm{CH}_{3} \mathrm{OOH}$ median mixing ratio was 110 pptv. Median mixing ratio was 110 pptv between $20^{\circ} \mathrm{S}$ and $17^{\circ} \mathrm{S}$, lower in the cloud free region between the two convergence zones (median value $96 \mathrm{pptv}$ ) and higher in the ITCZ region (median value 120 pptv). $\mathrm{H}_{2} \mathrm{O}_{2}$ median value was higher north of $20^{\circ} \mathrm{S}$ (median value $174 \mathrm{pptv}$ ) compare to south of $20^{\circ} \mathrm{S}$ (median value $148 \mathrm{pptv}$ ) in the upper troposphere. According to Mari et al. [2002], the mixing ratios of $\mathrm{H}_{2} \mathrm{O}_{2}$ north of $20^{\circ} \mathrm{S}$ were attributed to upper tropospheric local photochemistry only, without invoking transport.

[12] Chemical signatures in the SPCZ region are shown in Figure 6. $\mathrm{CO}$ in the relatively pristine tropical air sampled during PEM-Tropics B was between 40 and 50 ppbv. Figure 6 shows a well marked latitudinal gradient with high $\mathrm{CO}$ mixing ratios above $10^{\circ} \mathrm{S}$, apparently of northern hemispheric origin [Staudt et al., 2001; Avery et al., 2001]. These higher CO mixing ratios are present also in the upper troposphere $(12 \mathrm{~km})$ as illustrated in the cross section along the flight track. South of the SPCZ, a maximum in CO is simulated at $12 \mathrm{~km}$. The origin of this upper tropospheric $\mathrm{CO}$ plume is related to transport of continental air masses from Australia [Pickering et al., 2001; Mari et al., 2002]. It is interesting to note that no manifest vertical gradient is simulated for $\mathrm{CO}$.

[13] Simulated ozone in the free troposphere has a well marked gradient with relatively low mixing ratios in the SPCZ convective region ( $20 \mathrm{ppbv}$ at $12 \mathrm{~km}$ ) compared to ozone mixing ratio south of the SPCZ (40 ppbv at the same altitude). The contrast reflects the convective transport of ozone depleted air from the marine boundary layer to the upper troposphere. It is worth noting that the $\mathrm{O}_{3}$ minima is not nearly as severe as seen somewhat farther north during Central Equatorial Pacific Experiment (less than 5 ppbv observed) [Kley et al., 1996] and which have also been largely attributed to convection [Lawrence 
et al., 1999]. The horizontal variation of $\mathrm{CO}$ and $\mathrm{O}_{3}$ delimits the region south of the SPCZ, in the SPCZ and north of the SPCZ.

[14] Cross sections along the flight track in Figure 6 clearly show the signature of SPCZ-related convection for more soluble species. Mixing ratios of $\mathrm{CH}_{3} \mathrm{OOH}$ are significantly enhanced in the upper troposphere up to $14 \mathrm{~km}$, due to transport by convection [Mari et al., 2000]. $\mathrm{H}_{2} \mathrm{O}_{2}$ is more soluble than $\mathrm{CH}_{3} \mathrm{OOH}$, scavenging by convective precipitation is thus more efficient and low mixing ratios are simulated below the SPCZ column. HCHO is less soluble than $\mathrm{H}_{2} \mathrm{O}_{2}$ but more soluble than $\mathrm{CH}_{3} \mathrm{OOH}$. Cross section of $\mathrm{HCHO}$ does not reveal any particular signature in the convective regions. A minimum of $\mathrm{HCHO}$ mixing ratios is simulated in the cloud free region between the SPCZ and ITCZ where no vertical transport is simulated. In this marine convective case, vertical transport of $\mathrm{HCHO}$ is limited by convective precipitations as we will see in section 4.3 .

\subsection{Comparison Between Model and Observations}

[15] The point by point comparison of observed and simulated mixing ratios is presented in Figure 7.

\subsection{1. $\mathrm{CH}_{3} \mathrm{OOH}$ and $\mathrm{H}_{2} \mathrm{O}_{2}$}

[16] The model captures $41 \%$ of the observed $\mathrm{CH}_{3} \mathrm{OOH}$ variance but tends to overestimate $\mathrm{CH}_{3} \mathrm{OOH}$ mixing ratios: the median simulated-to-observed mixing ratio is 1.2 and the slope of the linear fit is 1.45 . Vertical profiles on both sides of the SPCZ reveal that the model overestimation is mainly located in the boundary layer (Figure 8). $\mathrm{H}_{2} \mathrm{O}_{2}$ is reasonably well represented by the model. The model captures $56 \%$ of the observed $\mathrm{H}_{2} \mathrm{O}_{2}$ variance (Figure 7). The median simulated-to-observed mixing ratio is 0.99 for $\mathrm{H}_{2} \mathrm{O}_{2}$ and the model reproduces well the vertical variations of $\mathrm{H}_{2} \mathrm{O}_{2}$ (Figure 8).

\subsubsection{HCHO}

[17] The model captures $60 \%$ of the observed variance but tends to underestimate the measured mixing ratios (the median simulated-to-observed mixing ratio is 0.49). In particular, the model fails to reproduce the peak of at $300 \mathrm{hPa}$ north of the SPCZ. Such a maximum of HCHO can be due to advection of HCHO-rich air or enrichment of upper tropospheric air by previous convective events. However, the underestimation of the enhancement of upper tropospheric mixing ratio by convection in the model cannot be excluded because of the underestimation of in the marine boundary layer. Underestimation of $\mathrm{HCHO}$ in the marine boundary layer can be due to a missing oceanic source of $\mathrm{HCHO}$ precursors (isoprene, acetone) in Meso-NH [Lewis et al., 2001; Zhou and Mopper, 1997; Ayers et al., 1997]. In the model, convection is not an efficient process to increase upper tropospheric and is thus unlikely to serve as a primary source of $\mathrm{HO}_{x}$.

4.2.3. $\mathrm{O}_{3}$

[18] In Figures 7 and 8 , the median simulated-toobserved mixing ratio for is 1.3 and the model captures only $29 \%$ of the observed variance. The model reproduces well the $\mathrm{O}_{3}$ mixing ratios increase in the upper troposphere above $350 \mathrm{hPa}$ south of the SPCZ but does not simulate the minimum of $\mathrm{O}_{3}$ at $300 \mathrm{hPa}$. Instead, the model simulates minimum mixing ratios in the whole 800-400 $\mathrm{hPa}$ region. Pickering et al. [2001] suggested that the plume of high $\mathrm{O}_{3}$ mixing ratio at $400 \mathrm{hPa}$ may have a nonconvective origin or that the source of the plume was located further back in time, allowing more photochemical processing during transport. Below $400 \mathrm{hPa}$, the model reproduces well the vertical gradient of ozone but underestimates the observed $\mathrm{O}_{3}$ in the southern drier region and overestimates the measured ozone in the cloudy region north of $20^{\circ} \mathrm{S}$.

\subsection{4. $\mathrm{OH}$ and $\mathrm{HO}_{2}$}

[19] The model captures $79 \%$ of the variance of the observed $\mathrm{H}_{2} \mathrm{O}$ concentrations. The median simulated-toobserved ratio is 1.0 and the slope of the linear fit is 0.97 . The simulation of $\mathrm{OH}$ mixing ratio is poorer but still satisfactory with $47 \%$ of the variance of the observed $\mathrm{OH}$ captured by the model. The median simulated-to-observed ratio is 0.9 and the slope is 0.77 . The good correlation of modeled $\mathrm{OH} \mathrm{H}_{2} \mathrm{O}$ and observed $\mathrm{OH}$ and is not surprising although the model tends to overestimate the $\mathrm{CH}_{3} \mathrm{OOH}$ mixing ratios and to underestimate the $\mathrm{HCHO}$ mixing ratios. According to Mari et al. [2002], the reaction $\mathrm{O}\left({ }^{1} \mathrm{D}\right)+\mathrm{H}_{2} \mathrm{O}$ is a major $\mathrm{HO}_{x}$ source in the most of the SPCZ region. Water vapor is well reproduced by the model with the least squares correlation coefficient between model and observations equal to 0.96 and the median ratio of simulated-to-observed mixing ratios equal to 0.64 (see also Figure 4).

\subsection{Convection, Advection, and Local Chemistry}

[20] In order to quantify the relative role of convection, advection, and local chemistry in the SPCZ convective region a series of budget calculations in the model is carried out for $\mathrm{HO}_{2}, \mathrm{CH}_{3} \mathrm{OOH}, \mathrm{HCHO}, \mathrm{H}_{2} \mathrm{O}_{2}$, and $\mathrm{O}_{3}$. These budget terms include sources tendencies of chemical species due to transport, convection (subgrid vertical lifting plus scavenging) and net gas phase chemical production. The net tendency of any chemical species in the model is given by:

$$
\frac{d C}{d t}=\left.\frac{d C}{d t}\right|_{\text {chemistry }}+\left.\frac{d C}{d t}\right|_{\text {convection }}+\left.\frac{d C}{d t}\right|_{\text {advection }}+\left.\frac{d C}{d t}\right|_{\text {turbulent mixing }}
$$

The budget terms were summed in horizontal and temporal ways by applying the following operator:

$$
\frac{1}{t_{2}-t_{1}} \sum_{t=t_{1}}^{t=t_{2}} \sum_{i} \sum_{j} P_{i, j}^{t} \Delta x \Delta y \Delta t
$$

where $P$ stands for a given process: advection, subgridscale convection (including wet deposition), chemistry, and turbulence. Spatial integration is performed over the horizontal subdomain defined by the Cartesian zone in Figure 2. This region corresponds to the convective SPCZ-related area traversed by the aircraft. This region is chosen because of the persistence of convective clouds. Advection process is the summation of horizontal plus vertical advection. It is worth noting that the advection tendencies obtained with this method may depend on the size of the subdomain that was chosen. Budget terms 


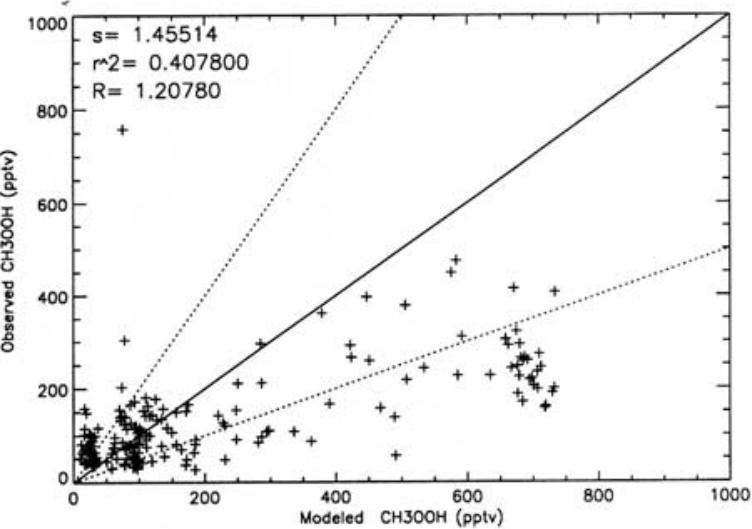

(a)

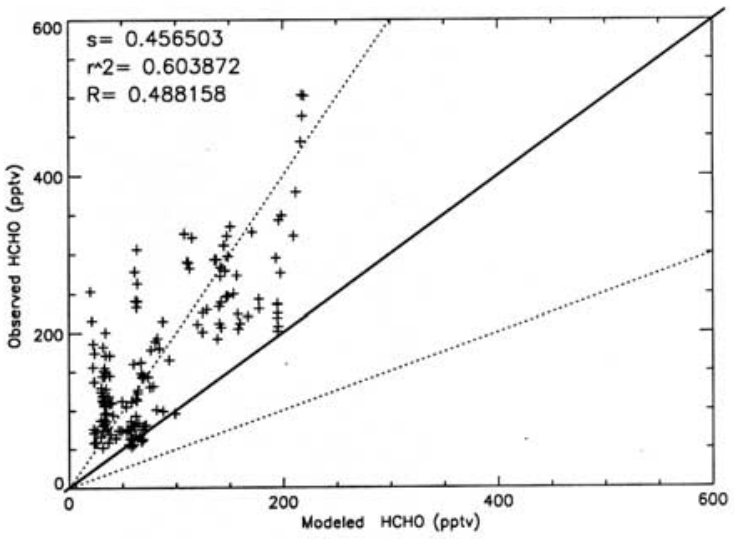

(c)

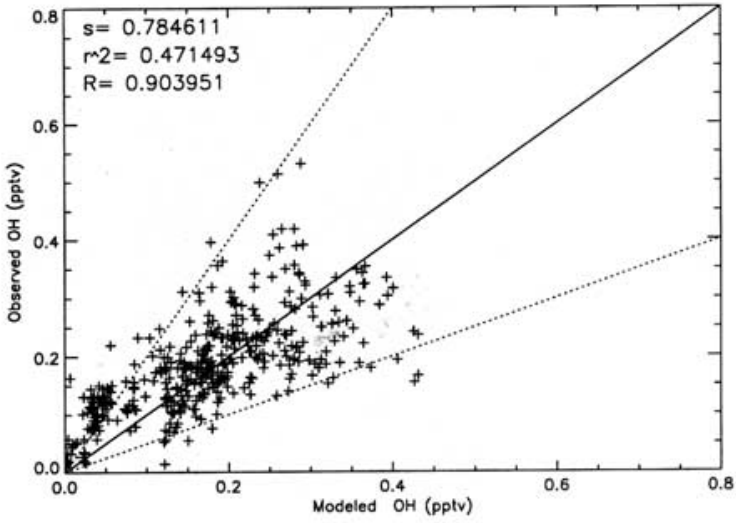

(e)



(b)

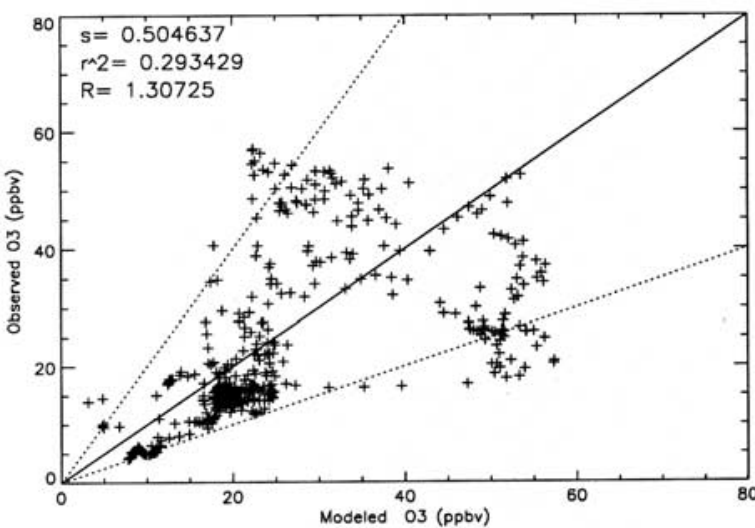

(d)

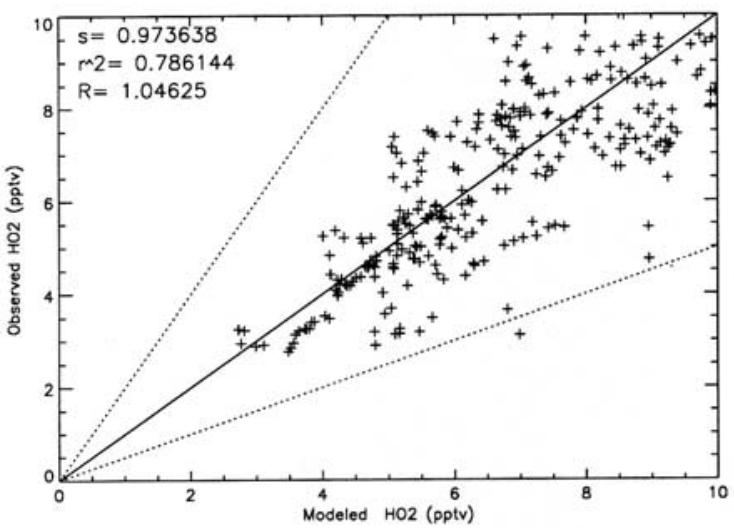

(f)

Figure 7. Point-by-point comparison between observations and model calculations for (a) $\mathrm{CH}_{3} \mathrm{OOH}$ mixing ratios (in pptv), (b) $\mathrm{H}_{2} \mathrm{O}_{2}$ mixing ratios (in ppbv), (c) $\mathrm{HCHO}$ mixing ratios (in pptv), (d) $\mathrm{O}_{3}$ mixing ratios (in pptv), (e) $\mathrm{OH}$ mixing ratios (in pptv), and (f) $\mathrm{HO}_{2}$ mixing ratios (in pptv). One-minute averages corresponding to PEM-Tropics B Flight 10 are shown by crosses. Model results are instantaneous model values at the exact time of the measurements. Model values are linearly interpolated at the location of the measurement. Also listed are the slope $(\mathrm{s})$ of the linear fit, the least squares correlation coefficient $\left(\mathrm{r}^{2}\right)$ between model and observations, and the median ratio $(\mathrm{R})$ of simulated-to-observed mixing ratios. The solid line in each panel is the $1: 1$ ratio and the dotted lines are the $2: 1$ and 1:2 ratios. 
(a)

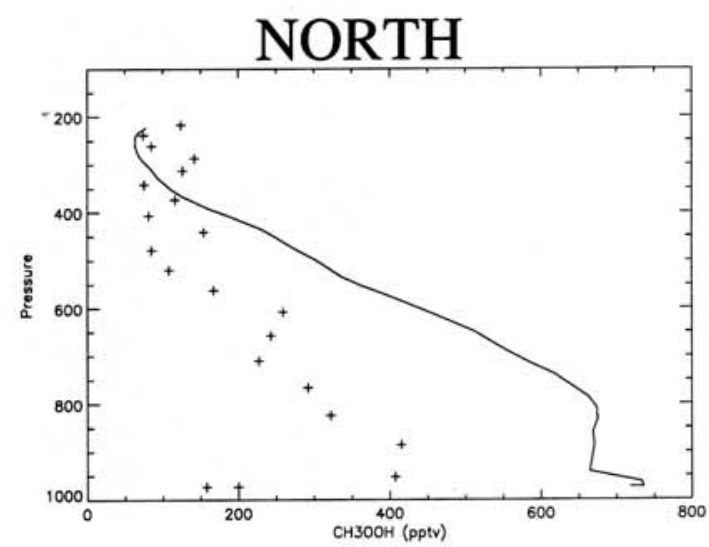

(b)



(c)

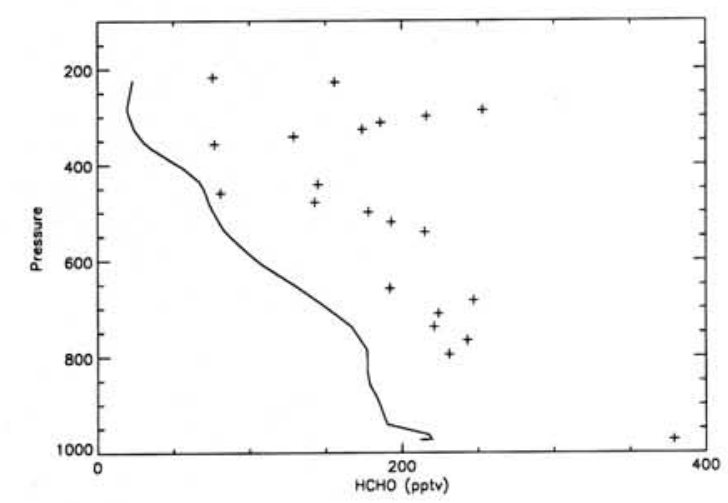

(d)

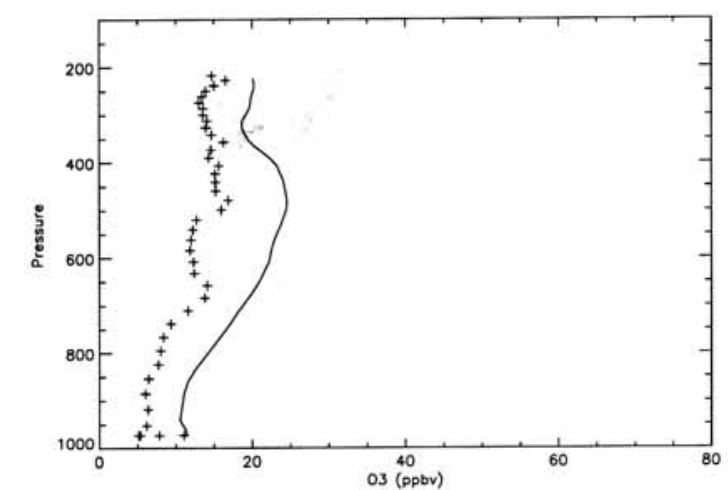

SOUTH
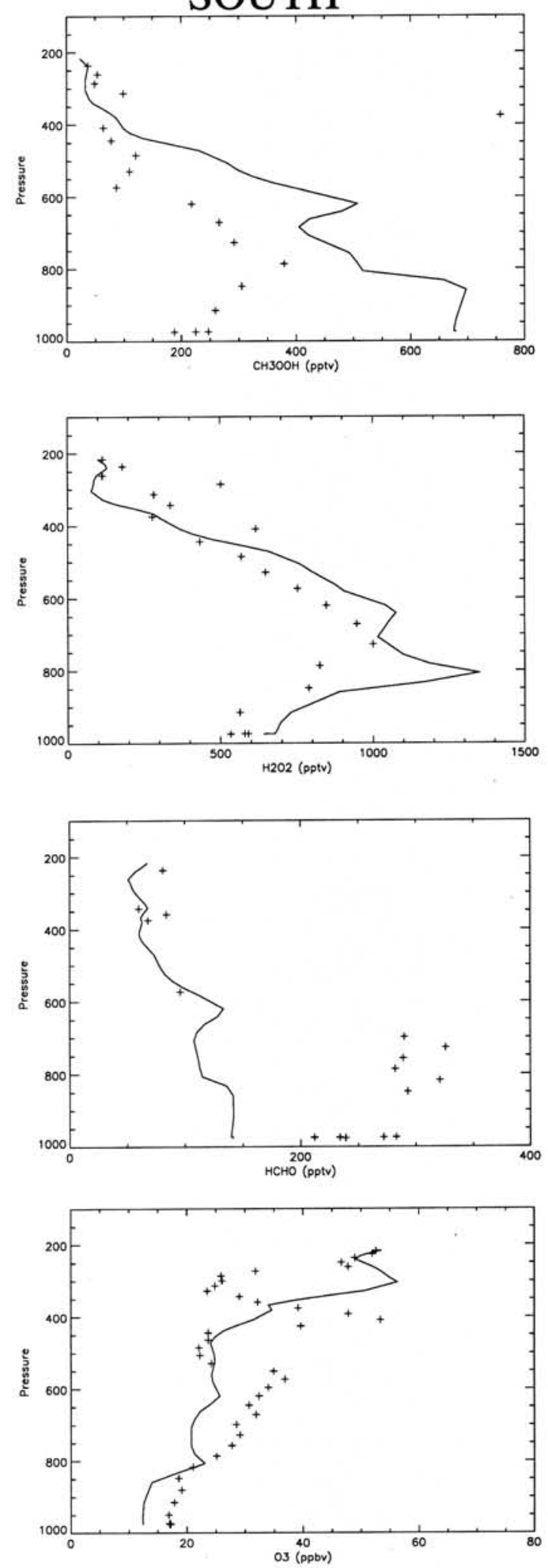

Figure 8. Vertical profiles south and north of the SPCZ of observations and model calculations for (a) $\mathrm{CH}_{3} \mathrm{OOH}$ mixing ratios (in pptv), (b) $\mathrm{H}_{2} \mathrm{O}_{2}$ mixing ratios (in ppbv), (c) $\mathrm{HCHO}$ mixing ratios (in pptv), and (d) $\mathrm{O}_{3}$ mixing ratios (in pptv). One-minute averages corresponding to PEM-Tropics B Flight 10 are shown by crosses. Model output is given as a solid line. 

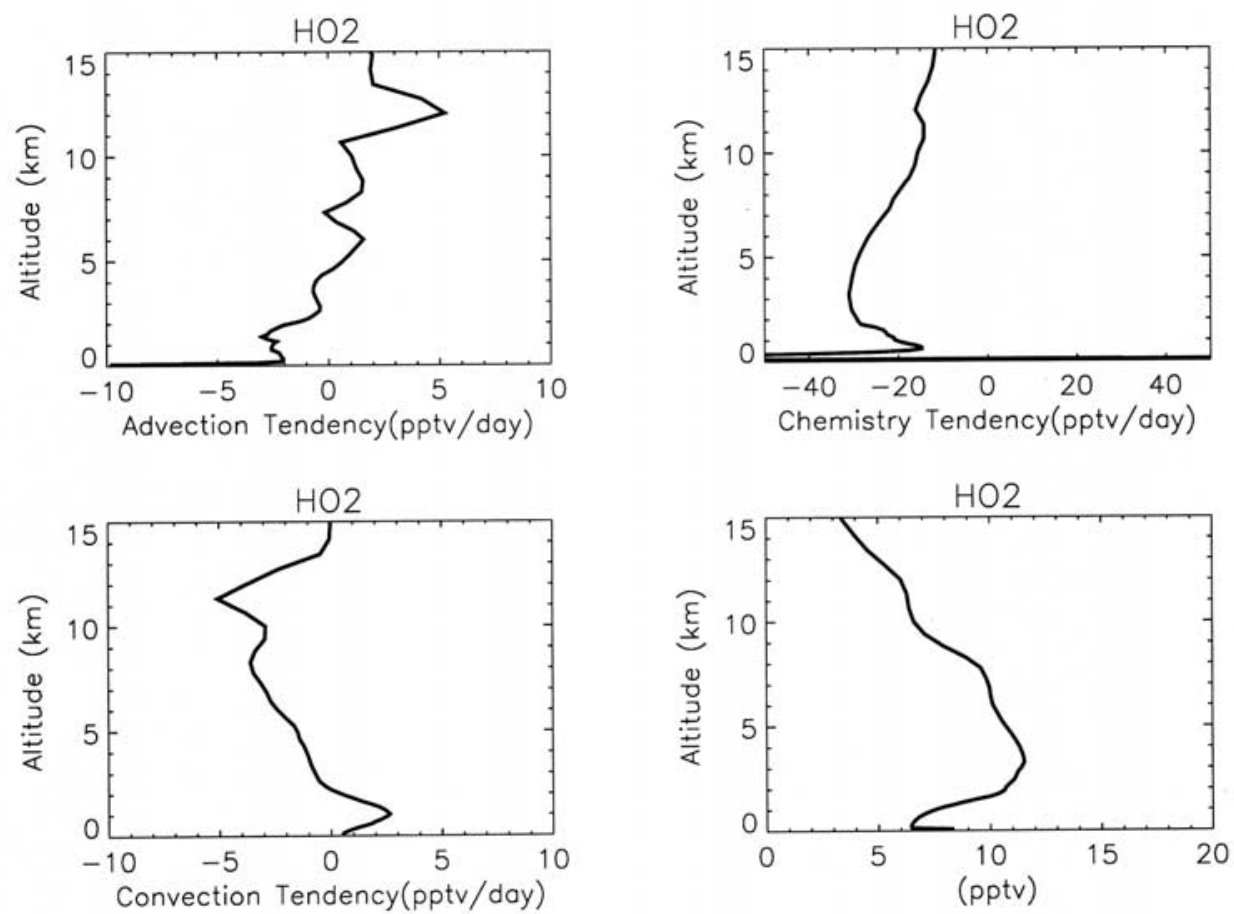

Figure 9. Averaged vertical profiles over the SPCZ (see Figure 2) and over the entire duration of the flight of $\mathrm{HO}_{2}$ source terms (in pptv/d) for (a) total advection, (b) chemistry, (c) convection, and (d) vertical profiles of $\mathrm{H}_{2} \mathrm{O}$ mixing ratios (in pptv).

have been integrated temporally over the entire duration of the flight $\left(t_{2}-t_{1}=8\right.$ hours $)$.

\subsection{1. $\mathrm{HO}_{2}$}

[21] Local chemistry prevails on the $\mathrm{HO}_{2}$ budget (Figure 9) as expected due to the short lifetime of the radical. Chem- istry source of $\mathrm{HO}_{2}$ is 4 times greater than convection sources with a strong diurnal variation, ranging from -40 to $40 \mathrm{pptv} / \mathrm{d}$. During the flight over the SPCZ region, scavenging by convective precipitation and convective transport eliminated on average $5 \mathrm{pptv} / \mathrm{d}$ of $\mathrm{HO}_{2}$ at 12
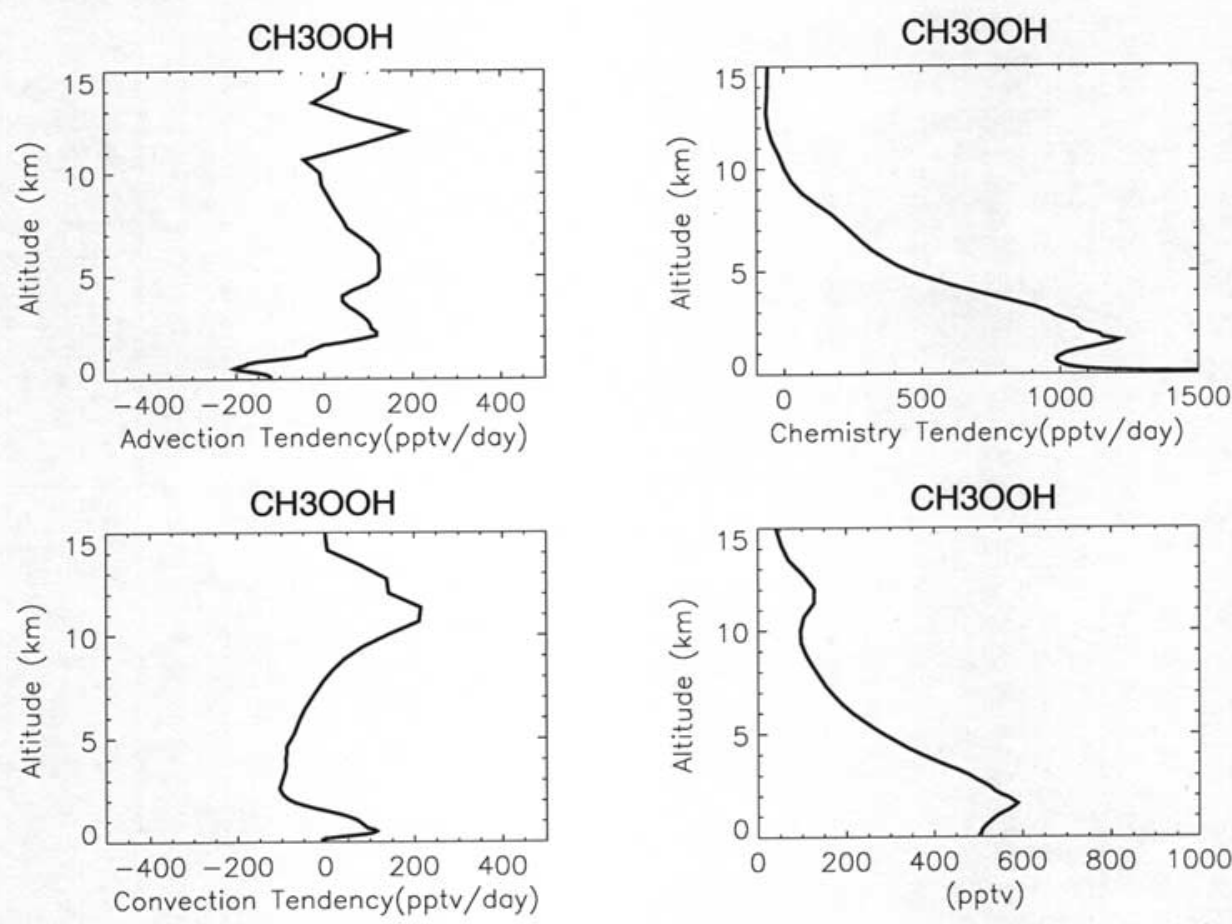

Figure 10. Same as Figure 9, but for $\mathrm{CH}_{3} \mathrm{OOH}$ source terms (in pptv/d) and vertical profiles of $\mathrm{CH}_{3} \mathrm{OOH}$ mixing ratios (in pptv). 



Figure 11. Same as Figure 9, but for $\mathrm{H}_{2} \mathrm{O}_{2}$ source terms (in ppbv/d) and vertical profiles of $\mathrm{H}_{2} \mathrm{O}_{2}$ mixing ratios (in ppbv).

$\mathrm{km}$. The loss of $\mathrm{HO}_{2}$ by convection in the $2-13 \mathrm{~km}$ region is partly balanced by the advection source.

\subsection{2. $\mathrm{CH}_{3} \mathrm{OOH}$}

[22] In Figure 10, chemistry is the main source of $\mathrm{CH}_{3} \mathrm{OOH}$ in the marine boundary layer (1000 pptv/d). Convection plays an important role in the vertical redistribution of $\mathrm{CH}_{3} \mathrm{OOH}$. Convective upward transport and scavenging by convective liquid precipitation deplete the $1-9 \mathrm{~km}$ layer at $100 \mathrm{pptv} / \mathrm{d}$. In the $10-15 \mathrm{~km}$ layer over the SPCZ region, transport by the convection brings air in the upper troposphere at $200 \mathrm{pptv} / \mathrm{d}$. $\mathrm{CH}_{3} \mathrm{OOH}$ transported by convection can act as a primary source of $\mathrm{HO}_{x}$. Mari et al. [2002] confirm this hypothesis. The authors found that in the cloud outflow region, $\mathrm{CH}_{3} \mathrm{OOH}$ accounted for $22-64 \%$ of the total primary source. It is worth noting that in the $2-8 \mathrm{~km}$ region, convective loss is mostly balanced by advection. Advected replenishes the midtroposphere in the SPCZ region.

\subsection{3. $\mathrm{H}_{2} \mathrm{O}_{2}$}

[23] $\mathrm{H}_{2} \mathrm{O}_{2}$ is a highly soluble gas. It is efficiently scavenged by liquid precipitation in the lower (warm) part of the clouds and to a much lesser extent in glaciated clouds [Mari et al., 2000; Barth et al., 2001]. Convection is a sink for $\mathrm{H}_{2} \mathrm{O}_{2}$ in the $2-13 \mathrm{~km}$ region with loss rate up to $0.3 \mathrm{ppbv} / \mathrm{d}$ (Figure 11). This effect is partly counteracted by chemical production below $5 \mathrm{~km}$ and advection above $3 \mathrm{~km}$.

\subsubsection{HCHO}

[24] The decrease of $\mathrm{HCHO}$ mixing ratios is driven by chemical loss within nearly the whole subdomain of budget calculation (Figure 12). Chemistry tendencies become slightly positive after 21 March at 0000 UTC in the boundary layer and 21 March at $0500 \mathrm{UTC}$ above $5 \mathrm{~km}$. HCHO is more soluble than $\mathrm{CH}_{3} \mathrm{OOH}$. Convection is a net sink for $\mathrm{HCHO}$ with loss by convective precipitation and upward transport of $50 \mathrm{pptv} / \mathrm{d}$ between 2 and $10 \mathrm{~km}$. However, convection tendency does not exhibit any enhancement in the upper troposphere: vertical transport of $\mathrm{HCHO}$ balances the scavenging of $\mathrm{HCHO}$ resulting in no net change in the SPCZ region. According to Mari et al. [2000], the authors found that $\mathrm{HCHO}$ was at the threshold for efficient scavenging allowing convection to increase upper tropospheric mixing ratios. They were studying a continental convective case sampled during the TRACE-A campaign. During this experiment, $\mathrm{HCHO}$ in the boundary layer was initially 20 times higher than in the background upper troposphere. In the marine convective case during PEM-Tropics B, HCHO in the background upper troposphere is initially only 3 times smaller than the mixing ratios observed in the boundary layer. In addition, convective updraft were less vigorous over ocean than they were over continent. The vertical gradient is thus significantly lower in the marine case and upward transport is expected to have less impact. The weaker updrafts in marine convection compared to continental convection would give smaller HCHO fluxes to the upper troposphere for the marine case. In addition, smaller vertical $\mathrm{HCHO}$ fluxes would be found for the marine case because of the smaller boundary layer concentrations compared to the continental case. In the model, $\mathrm{HCHO}$ is thus unlikely to serve as a primary source of $\mathrm{HO}_{x}$ in this marine upper tropospheric case.

4.3.5. $\mathrm{O}_{3}$

[25] In Figure 13, convection brings $\mathrm{O}_{3}$-poor air from the boundary layer to higher altitudes inducing negative convection tendency above $5 \mathrm{~km}$ [Folkins et al., 2002]. As 

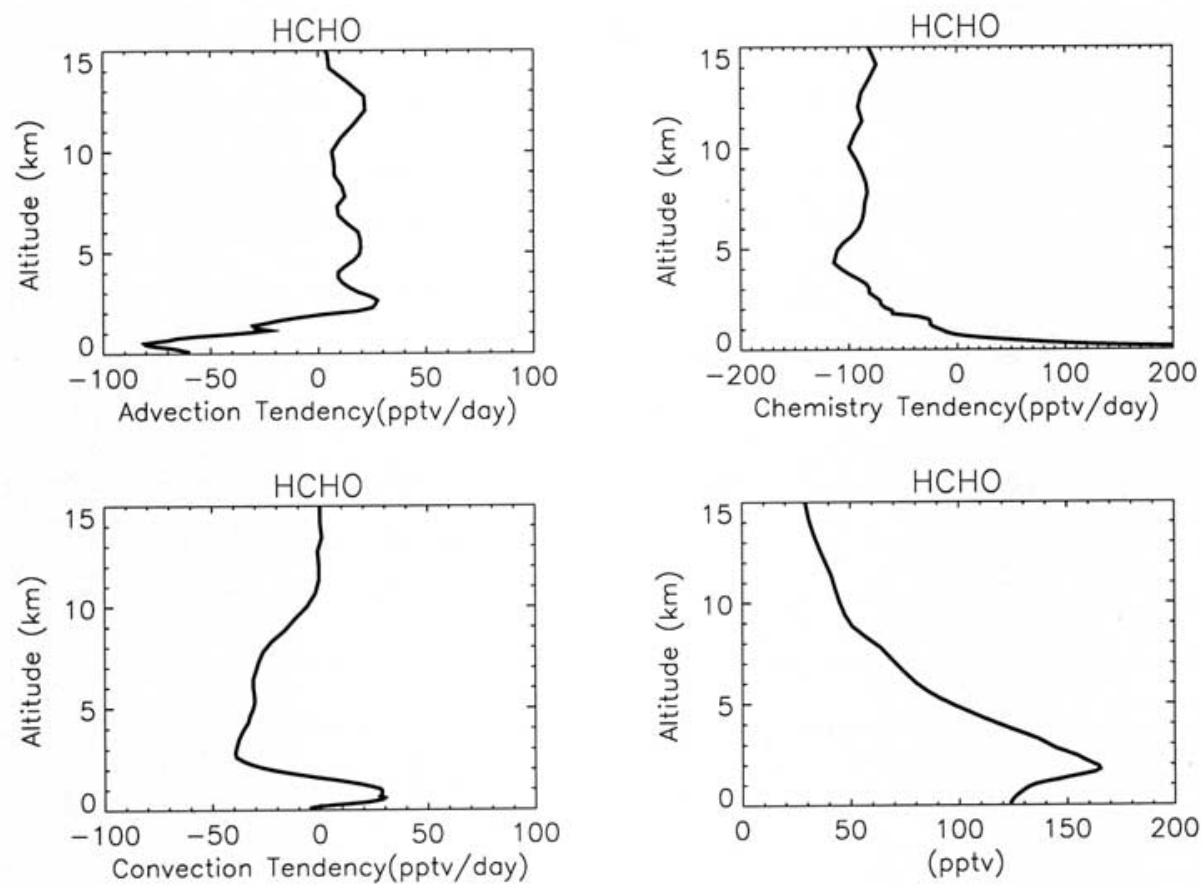

Figure 12. Same as Figure 9, but for HCHO source terms (in pptv/d) and vertical profiles of HCHO mixing ratios (in pptv).

a consequence, a minimum in $\mathrm{O}_{3}$ mixing ratio is obtained between 9 and $12 \mathrm{~km} . \mathrm{O}_{3}$ starts increasing significantly above $12 \mathrm{~km}$ whereas convection tendency reaches its largest negative values. Increase of ozone mixing ratio is due to advection of rich ozone air in the 11-13 km region. Ozone chemical term is low (less than $2 \mathrm{ppbv} / \mathrm{d}$ ) in the upper troposphere as expected in a $\mathrm{NO}_{x}$-limited regime.
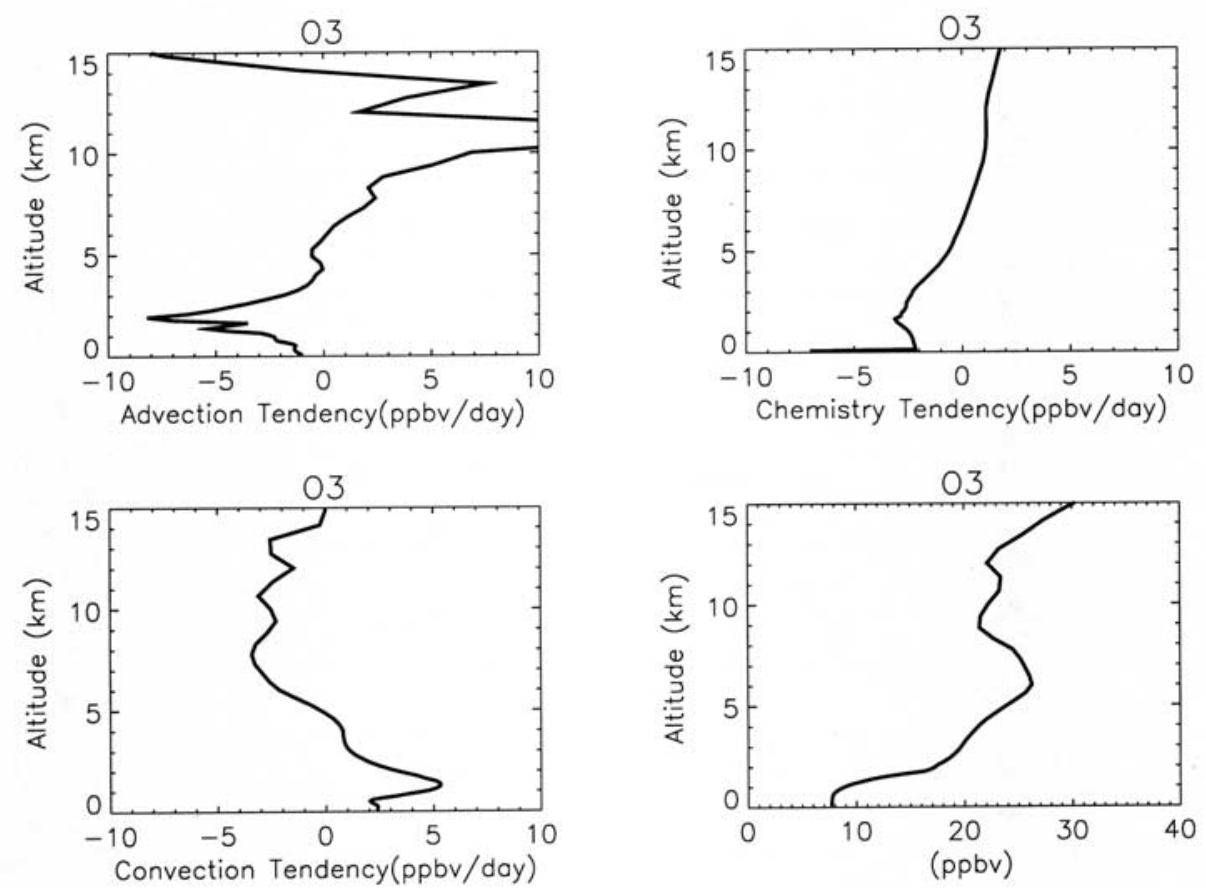

Figure 13. Same as Figure 9, but for $\mathrm{O}_{3}$ source terms (in ppbv/d) and vertical profiles of $\mathrm{O}_{3}$ mixing ratios (in ppbv). 


\section{Conclusion}

[26] A three-dimensional mesoscale model, Meso-NH, coupled on-line with chemistry and an entraining-detraining plume model is applied to study the factors controlling $\mathrm{HO}_{x}$ radicals and their precursors during an SPCZ convection event sampled by the PEM-Tropics B aircraft mission.

[27] Near the surface $(950 \mathrm{hPa})$ and at very low pressure $(200 \mathrm{hPa})$, the SPCZ acts as a barrier to mixing of tropical and subtropical air. On the contrary, in the $400-270 \mathrm{hPa}$ region, the convergence zone becomes porous allowing subtropical air masses from the Southern Hemisphere to mix with tropical air from NE of the SPCZ. The present study suggests that air south of the SPCZ can also traverse the SPCZ at midtropospheric levels where it is entrained in the convective clouds.

[28] The point by point comparison of simulated and $1 \mathrm{~min}$ average observed mixing ratios reveals that the model is able to reproduce well the $\mathrm{HO}_{x}$ mixing ratios. The model also captures the contrast between northern and southern air masses. Convection brings $\mathrm{O}_{3}$-poor air at higher altitude, generating a minimum in $\mathrm{O}_{3}$ mixing ratio between 9 and $12 \mathrm{~km}$. Ozone local chemistry source is low $(<2 \mathrm{ppbv} / \mathrm{d})$ in the upper troposphere as may be expected in a $\mathrm{NO}_{x}$-limited regime.

[29] The model captured $56 \%$ of the observed $\mathrm{H}_{2} \mathrm{O}_{2}$ variance and $41 \%$ of the observed $\mathrm{CH}_{3} \mathrm{OOH}$ variance. Vertical variations of $\mathrm{H}_{2} \mathrm{O}_{2}$ are remarkably well reproduced. Scavenging by convective precipitation and upward transport eliminate $\mathrm{H}_{2} \mathrm{O}_{2}$ in the $2-15 \mathrm{~km}$ region. The model overestimates the observed $\mathrm{CH}_{3} \mathrm{OOH}$ mixing ratio mainly in the boundary layer. Convection plays an important role in the vertical distribution of $\mathrm{CH}_{3} \mathrm{OOH}$ with efficient vertical transport from the boundary layer to the $10-15 \mathrm{~km}$ region. Therefore, in the upper troposphere over the SPCZ region, $\mathrm{CH}_{3} \mathrm{OOH}$ transported by convection can act as a primary source of $\mathrm{HO}_{x}$.

[30] The model captures $60 \%$ of the observed variance but fails to reproduce a peak of mixing ratio at $300 \mathrm{hPa}$ sampled during the northern spirals. Simulated does not exhibit any increase in the upper troposphere. This result contrasts with continental convective, more vigorous, systems, for which stronger updrafts and steeper vertical gradients of mixing ratios lead to strong enhancement of $\mathrm{HCHO}$ in the upper troposphere. Thus, in this marine case, HCHO is unlikely to serve as a primary source of $\mathrm{HO}_{x}$ in the upper troposphere. Underestimation of $\mathrm{HCHO}$ in the marine boundary layer suggests a missing oceanic source of $\mathrm{HCHO}$ precursors (isoprene and acetone).

[31] Acknowledgments. Computational resources were provided by the Institute for Development and Resources in Intensive Scientific Computing. J. Duron, S. Prieur, D. Gazen, and J. Escobar are acknowledged for their precious assistance. This work was supported by the French Programme National de Chimie Atmospherique. The authors want to thank H. Fuelberg, M. Lawrence, and an anonymous reviewer for their useful comments.

\section{References}

Ayers, G. P., R. W. Gillett, H. Granek, C. deServes, and R. A. Cox, Formaldehyde production in clean marine air, Geophys. Res. Lett., 24, $401-$ 404, 1997.

Avery, M. A., D. J. Westberg, H. E. Fuelberg, R. E. Newell, B. E. Anderson, S. A. Vay, G. W. Sachse, and D. R. Blake, Chemical transport across the ITCZ in the central Pacific during an El Niño-Southern Oscillation cold phase event in March-April 1999, J. Geophys. Res., 106, 32,53932,553, 2001.

Barth, M. C., A. L. Stuart, and W. C. Skamarock, Numerical simulations of the July 10, 1996 Stratospheric-Troposperic Experiment: Radiation, Aerosols, and Ozone (STERAO)-Deep convection experiment storm: Redistribution of soluble tracers, J. Geophys. Res., 106, 12,38112,400, 2001.

Chang, J. S., R. A. Brost, I. S. A. Isaksen, S. Madronich, P. Middleton, W. R. Stockwell, and C. J. Walcek, A three dimensional Eulerian acid deposition model: Physical concepts and formulation, J. Geophys. Res., 92, 14,681-14,700, 1987.

Collins, W. J., D. S. Stevenson, C. E. Johnson, and R. G. Derwent, Role of convection in determining the budget of odd hydrogen in the upper troposphere, J. Geophys. Res., 104, 26,927-26,941, 1999.

Cooper, O. R., J. L. Moody, D. D. Parrish, M. Trainer, T. Ryerson, G. Hubler, F. Fehsenfeld, S. J. Oltmans, and M. J. Evans, Trace gas signatures of the airstreams within the North Atlantic cyclones: Case studies from the NARE'97 aircraft intensive, J. Geophys. Res., 106, 5437-5456, 2001.

Crassier, V., K. Suhre, P. Tulet, and R. Rosset, Development of a reduced chemical scheme for use in mesoscale meteorological models, Atmos. Environ., 34, 2633-2644, 1999.

Folkins, I., C. Braun, A. M. Thompson, and J. C. Witte, Tropical ozone as an indicator of deep convection, J. Geophys. Res., 107(D13), 4184, doi:10.1029/2001JD001178, 2002.

Fuelberg, H. E., R. E. Newell, D. J. Westberg, J. C. Maloney, J. R. Hannan, B. C. Martin, and Y. Zhu, A meteorological overview of the second Pacific Exploratory Mission in the Tropics, J. Geophys. Res., 106, 32,427-32,443, 2001.

Gettelman, A., M. L. Salby, W. J. Randel, and F. Sassi, Convection in the tropical region and stratosphere-troposphere exchange, SPARC Newsl., $17,22-25,2001$

Gregory, G. L., et al., Chemical characteristics of Pacific tropospheric air in the region of the ITCZ and SPCZ, J. Geophys. Res., 104, 5697-5716, 1999.

Hesstvedt, E., O. Hov, and I. S. A. Isaksen, Quasi-steady state approximation in air pollution modelling: Comparison of two numerical schemes for oxidant prediction, Int. J. Chem. Kinet., 10, 4148-4156, 1978.

Jaeglé, L., et al., Observed $\mathrm{OH}$ and $\mathrm{HO}_{2}$ in the upper troposphere suggest a major source from convective injection of peroxides, Geophys. Res. Lett., 24, 3181-3184, 1997.

Jaeglé, L., D. J. Jacob, W. H. Brune, and P. O. Wennberg, Chemistry of $\mathrm{HO}_{x}$ radicals in the upper troposphere, Atmos. Environ., 35, 469-489, 2001.

Kley, D., P. J. Crutzen, H. G. J. Smit, H. Voemel, S. J. Oltmans, H. Grassl, and V. Ramanathan, Observations of near-zero ozone concentrations over the convective Pacific: Effects on air chemistry, Science, 274, 230-233, 1996.

Lafore, J. P., et al., The Meso-NH Atmospheric simulation system, I, Adiabatic formulation and control simulations, Ann. Geophys., 16, 90-109, 1998.

Lawrence, M. G., P. J. Crutzen, and P. J. Rash, Analysis of the CEPEX ozone data using a 3D chemistry-meteorology model, Q. J. R. Meteorol. Soc., 125, 2987-3009, 1999.

Lewis, A. C., L. J. Carpenter, and M. J. Pilling, Nonmethane hydrocarbons in Southern Ocean boundary layer air, J. Geophys. Res., 106, 49874994, 2001.

Madronich, S., and G. Weller, Numerical integration errors in calculated tropospheric photodissociation rate coefficients, J. Atmos. Sci., 10, 289300, 1990.

Mari, C., K. Suhre, R. Rosset, T. S. Bates, B. J. Huebert, A. R. Bandy, D. C. Thornton, and S. Businger, 1D modeling of sulfur species during the First Aerosol Characterisation Experiment (ACE-1) Lagrangian B, J. Geophys. Res., 21,733-21,749, 1999

Mari, C., D. J. Jacob, and P. Bechtold, Transport and scavenging of soluble gases in a deep convective cloud, J. Geophys. Res., 105, 22,255-22,267, 2000 .

Mari, C., et al., Sources of upper tropospheric $\mathrm{HO}_{x}$ over the South Pacific Convergence Zone: A case study, J. Geophys. Res., 107, doi:10.1029/ 2001JD001466, in press, 2002.

McKeen, S. A., T. Gierczak, J. B. Burholder, P. O. Wennberg, T. F. Hanisco, E. R. Keim, R.-S. Gao, S. C. Liu, A. R. Ravishankara, and D. W. Fahey, The photochemistry of acetone in the upper troposphere: A source of odd-hydrogen radicals, Geophys. Res. Lett., 24, 3177-3180, 1997.

Pickering, K. E., et al., Convective transport of biomass burning emissions over Brazil during TRACE-A, J. Geophys. Res., 101, 23,993-24,012, 1996.

Pickering, K. E., et al., Trace gas transport and scavenging in PEM TropicsB SPCZ convection, J. Geophys. Res., 106, 32,591-32,602, 2001.

Prather, M. J., and D. J. Jacob, A persistent imbalance in and $\mathrm{NO}_{x}$ photochemistry of the upper troposphere driven by deep tropical convection, Geophys. Res. Lett., 24, 3189-3192, 1997.

Raper, J. L., M. M. Kleb, D. J. Jacob, D. D. Davis, R. E. Newel, H. E. Fuelberg, R. J. Bendura, J. M. Hoell, and R. J. McNeal, Pacific explora- 
tory mission in the tropical Pacific: PEM-Tropics B, March-April 1999 J. Geophys. Res., 106, 32,401-32,423, 2001.

Singh, H., Y. Chen, A. Staudt, D. Jacob, D. Blake, B. Heikes, and J. Snow, Evidence from the Pacific troposphere for large global sources of oxygenated organic compounds, Nature, 410, 1078-1081, 2001

Staudt, A. C., D. J. Jacob, J. A. Logan, D. Bachiochi, T. N. Krishnamurti, and G. W. Sachse, Continental sources, transoceanic transport, and interhemispheric exchange of carbon monoxide over the Pacific, J. Geophys. Res., 106, 32,571-32,589, 2001.

Suhre, K., et al., Chemistry and aerosols in the marine boundary layer: 1-D modelling of the three ACE-2 Lagrangian experiments, Atmos. Environ., 34, 5079-5094, 2000.

Tulet, P., V. Crassier, F. Solmon, D. Guedalia, and R. Rosset, Regional pollution modelling - Description of the Meso-NH-C model and application to a transboundary pollution episode between northern France and southern England, J. Geophys. Res., 107, doi:10.1029/2000JD000301, in press, 2002.

Vincent, D. G., The South Pacific Convergence Zone (SPCZ): A review, Mon. Weather Rev., 122, 1949-1970, 1994.

Wennberg, P. O., et al., Hydrogen radicals, nitrogen radicals and the production of $\mathrm{O}_{3}$ in the upper troposphere, Science, 279, 49-53, 1998.

Wennberg, P. O., et al., Twilight observations suggest unknown sources of $\mathrm{HO}_{x}$, Geophys. Res. Lett., 26, 1373-1376, 1999.
Zhou, X. L., and K. Mopper, Photochemical production of low-molecularweight carbonyl compounds in seawater and surface microlayer and their air-sea exchange, Mar. Chem., 56, 201-213, 1997.

M. A. Avery, Department of Physics, Hampton University, Hampton, VA 29668, USA.

W. H. Brune, Department of Meteorology, Pennsylvania State University, University Park, PA 16802-5013, USA.

I. Faloona, Atmospheric Chemistry Division, National Center for Atmospheric Research, Boulder, CO 80305, USA.

B. G. Heikes, Center for Atmospheric Chemistry Studies, University of Rhodes Island, Narragansett, RI 02882, USA.

D. J. Jacob and A. Staudt, Division of Engineering and Applied Science, Harvard University, Cambridge, MA 02138, USA.

C. Mari and C. Saüt, Laboratoire d'Aérologie, UMR CNRS/Université Paul Sabatier, Toulouse, F-31400, France. (marc@aero.obs-mip.fr)

G. W. Sachse, Nasa Langley Research Center, Hampton, VA 23681, USA.

S. T. Sandholm and D. Tan, Earth and Atmospheric Sciences, Georgia Institute of Technology, Baker Building, Atlanta, GA 30332, USA.

H. B. Singh, NASA Ames Research Center, Moffett Field, CA 94035 , USA. 